\title{
FISHERMEN'S PERCEPTION OF THE BENEFITS OF USING ICT IN RELATIONSHIP WITH FISHERMEN'S INCOME AND STAKEHOLDER STRATEGIES: A CASE STUDY IN PATI REGENCY-CENTRAL JAVA
}

\author{
Ika Suciati \\ Faculty of Economics and Business, Universitas Diponegoro, Semarang \\ Email: ikasuci741@gmail.com (corresponding author) \\ Indah Susilowati \\ Faculty of Economics and Business, Universitas Diponegoro, Semarang \\ Email:prof.indah@gmail.com
}

Received: December 2021; Accepted: December 2021; Available online: January 2022

\begin{abstract}
The potential of fisheries resources is still massive as well as the challenges. One of the challenges faced in the fisheries sector is climate change occurring massively. Climate change that occurs disrupts the productivity and activities of fishermen. Fishermen live with uncertainty because their livelihoods are directly related to nature. This is because fishermen's livelihoods are very dependent on natural conditions. To deal with natural changes that occur very rapidly, it requires fishermen to adapt and mitigate, one of which is by utilizing information and communication technology. The technology created is available in various forms, such as android-based applications, SMS broadcasts, Whatsapp groups, GPS, Fishfinder, etc. The objective of this study is to identify fishermen's perception of the benefits of technology and service communication used, ICT relationship with fishermen's income, and stakeholder role strategies in the use of ICT. The mix-method approach is used to acknowledge study objectives using the software SPSS 23 and Atlas. Ti 8. The result shows that fishermen's perception of the benefits of ICT namely facilitating communication, reducing production costs, improving safety, increasing fishermen's knowledge, and increasing income. There is a relationship between the use of ICT and fishermen's income, as well as stakeholders who have an important role in the use of ICT in the fishing community.
\end{abstract}

Keywords: Fishermen, ICT; Benefits; Income; Role.

\begin{abstract}
Abstrak
Potensi sumber daya perikanan tersebut sesungguhnya masih sangat besar akan tetapi tantangan yang dihadapi juga cukup besar. Salah satu yang menjadi tantangan yang dihadapi dalam sektor perikanan yaitu perubahan iklim yang dewasa ini terjadi sangat masif. Perubahan iklim yang terjadi mengganggu produktivitas maupun aktivitas nelayan. Hal ini dikarenakan mata pencaharian nelayan yang sangat bergantung dengan keadaan alam. Untuk menghadapi perubahan alam yang terjadi sangat pesat mengharuskan nelayan melakukan adaptasi dan mitigasi, salah satunya yaitu dengan memanfaatkan teknologi informasi dan komunikasi. Teknologi yang diciptakan tersedia dalam berbagai bentuk, seperti aplikasi berbasis android, broadcast SMS, grup Whatsapp, GPS, Fish finder dan sebagainya. Tujuan dari penelitian ini yaitu untuk mengidentifikasi persepsi nelayan terhadap manfaat teknologi dan komunikasi kenelayanan yang digunakan, hubungan TIK dengan pendapatan nelayan serta strategi peran stakeholder dalam penggunaan TIK. Pendekatan mix-method digunakan untuk menjawab tujuan penelitian dengan menggunakan alat bantu software SPSS 23 dan Atlas.Ti 8. Hasil penelitian menunjukkan persepsi nelayan tentang manfaat TIK yaitu memudahkan komunikasi, mengurahi biaya produksi, meningkatkan keselamatan, meningkatkan pengetahuan nelayan dan meningkatkan pendapatan. Terdapat hubungan antara penggunaan TIK dengan pendapatan nelayan, serta Stakeholder yang memiliki peran penting dalam penggunaan TIK pada masyarakat nelayan.
\end{abstract} Kata Kunci: Nelayan; TIK; Manfaat; Pendapatan; Peran. 
How to Cite: Suciati, I. \& Susilowati, I. (2022). Fishermen's Perception of the Benefits of Using ICT in Relationship with Fishermen's Income and Stakeholder Strategies: A Case Study in Pati Regency-Central Java. Media Ekonomi dan Manajemen, 37(1), 127-139. doi: http://dx.doi.org/10.24856/mem.v37i1.2646.

\section{INTRODUCTION}

Global climate change is an issue that is giving the attention of the world community. This is especially the impact on human life (Perdana, 2015). Climate change also has an impact on fishing activities conducted by fishermen, the presence of tidal waves, erratic wind direction, rainfall, and the unpredictable rainy season will have an impact on fishing activities by fishermen, changes in income received by fishermen, and their wellbeing. The social and economic conditions of fishermen in Indonesia are concerning inseparable from poverty and economic uncertainty, especially now that fishermen are faced with the threat of climate change. (Akbar \& Huda, 2017)

The government attention related to adaptation and mitigation to climate change is regulated in the Minister of Home Affairs Regulation No. 30 of 2010 on Guidelines for Resource Management in Marine Areas section four article 18 affirms local governments in preparing resource management planning in marine areas, must include materials that contain efforts to adapt and mitigate the effects of climate change.

Fishermen in determining the decision to go to sea require information about fishing areas, weather information, fish price information, marine dynamics information, and electronics logbook fishing. This information is necessary required by fishermen before going to sea. During this time, generally traditional fishermen get information based on their own experience, the others get information from various sources, such as radio, boat owners, fishing ports, or information from other fishermen. Fishermen still have difficulty in getting access to information from these sources. The lack of information that fishermen have about the information required in fishing activities becomes one of the causes of bargaining position fishermen become weak. (Tyas, 2016)

In today's digital era, strengthening fishing efforts is by providing the information needed by fishermen for fishermen. The information helps fishermen in their livelihood, so it is expected that fishermen's productivity can increase which will have an impact on improving fishermen's welfare. Although there is currently a lot of information conveyed to the public through the web, social media, applications, or broadcast SMS, the information is only conveyed to certain fishermen who have access to get the information. Many fishermen are lack information and communication technology, in addition to a lack in the information conveyed. Improvements are required to information technology and synergy between the central government, region, and related stakeholders.

The study conducted by Susilowati, et al (2020) discussed the use of information technology and information by fishermen and is very helpful for them in doing sea activities. Although it was not explained in detail how the benefits were felt by fishermen and only explained using the perception of fishermen. While Nugroho et al (2021), discussed the awareness of fishermen in using low information technology. Information and communication technology is very useful for fishermen, especially in their sea activities. As explained by Fadzil et al (2019) information technology has four benefits, namely increasing productivity and combating productivity, reducing digital inequality among rural communities, improving technology literacy among small fishermen, and safety issues among small fishermen.

This study aims to find out the perceptions of fishermen and stakeholders related to the use of information and communication technology and know the 
relationship of the use of information and communication technology (ICT) with fishermen's productivity.

\section{LITERATURE REVIEW Fisherman}

The fishing community is one part of Indonesian society that depends on its life through the potential of fishery resources. Fishing communities have their social characteristics as a community living in coastal areas compared to people living on land. The complexity of the problems that occur in the fishing community is caused by the fishing community living in a harsh natural atmosphere that is always overwhelmed with uncertainty in conducting its business. (Fargomeli, 2014)

\section{Technology in fisheries}

Fishing gear technology is a tool to catch fish, both inland and in the ocean. Based on the technology used, the fishing community is divided into two groups, namely traditional fishing communities and modern fishing communities. Traditional fishermen are people who do their livelihood activities using simple tools, such as fishing rods, spears, swords, stabbings, sero, and seke. They catch fish only in shallow seas by catching while standing on the beach or using a canoe boat. While modern fishermen are people who do their livelihood activities by using tools that can be categorized modern, for example by using motorboats with Bagan fishing gear, rumpon, or purse seine. (Wijaya et al, 2009)

\section{The Role of Technology in Fishermen's Productivity}

The positive correlation between radio use and fish farming productivity implies that the more often farmers listen to agricultural information about fish farming technology from radio, they are excited to increase their fish farming productivity. On the other hand, the positive correlation between mobile phone use and fish farming productivity implies that the more often farmers communicate and share information regarding fish farming technology, they will increase their fish farming productivity. (Lamtane et al, 2018)

To support this, Jehan et al (2014) reported that farmers who used mobile phones for more than five hours per week to communicate with agricultural experts earned higher yields than those who used less than four hours. A study by Otter \& Theuvsen, (2014) confirmed that the use of mobile phones to communicate with trading partners in Chile had a major positive impact on the productivity of small raspberry farms. Actually, with mobile phones, farmers can have the ability to exchange relevant and credible information promptly that can help them to make the right decisions about fish production and increase their production.

According to Fatmawati, (2015), the technology acceptance model is a simple model for predicting the acceptance and use of technology. This model describes the beliefs, attitudes, interests, and behavioral relationships of users using a psychological theory approach. Tasmil \& Herman, (2015) modified TAM using five indicators, namely perceived ease of use, perceived usefulness, attitude toward using, behavioral intention to use, and actual system usage) to analyze the acceptance rate of GPS technology for fishermen.

\section{Perception and Stakeholder Analysis in the use of Technology in fishermen}

Adaptation and technological innovation that occurs partially in fishing boats and fishing gear leads to the development of traditional fishing technology Salam, et al (2021). In line with the demand for development, fishing communities have been proposed various types of equipment and advanced technology to assist their fishing operations. Technologies such as sonar, echo sounder, a global positioning system 
(GPS), radar, and more traditional methods such as mobile phones and wireless devices, have been shown to improve the socio-economic aspects of the fishing industry Hassan et al (2011). The use of LED lamps in totabito fishing gear is an innovation conducted by fishermen independently. In the reality, the tool can increase the catch. (Salam et al., 2021)

The Research Center of the Ministry of Maritime Affairs and Fisheries utilizes NOAA \pm AVHRR, TOPEX / POSEIDON, SEASTAR satellite data to obtain sea surface temperature data, sea level data, chlorophyll-a concentration data, and is equipped with wind data, waves from BMG, and data from LAPAN to create a Fishing Ground Map. The fishermen who have used this technology are no longer looking for and guessing the whereabouts of fish. Information on potential fish locations is already included in the forecast map for fishing areas. In addition, satellites can be used to determine the position of the vessel at sea (vessel position), the placement of FADs with the help of a global positioning system (GPS) tool quickly and accurately and to obtain information on fishing areas via satellite radio. (Wiryadi, 2015)

The number of fishermen in Indonesia is dominated by small-scale fishermen and traditional fishermen. The large number of small fishermen and traditional fishermen who exceed the capacity of the fishing area can trigger the potential for fishing, this is because the reach of the fishing area for small fishermen is limited which is not comparable to the fishing area. Such conditions can also trigger conflicts between fishermen due to the struggle for fishing areas. There is a need for a solution to this problem. One solution that has been done by the Government is to assist with fishing vessels that are over 10 GT in size so that they can fish with a further range than before. In general, their relatively short working hours are usually just one day (one-day fishing). That condition or habit has an impact on the catch that is not optimal so the results in low production levels and their income is also not optimal as a result their level of welfare is low. The working system one-day fishing is also caused by vessel and fishing gear that they use and the work culture only one day becomes a habit. So that the government program with increased vessel size and change their working system seem difficult to implement. This condition is also an obstacle with data collection and guidance conducted by the Government or Regional Government. (Retnowati, 2011)

Observing the condition of the fishing sector, especially about the number of fishermen, can be used as an assessment or indicator that the fishing sector in Indonesia is still dominated by traditional fishermen with a small fishing scale as well. For that, steps are needed that can change the situation, work culture, and improve their skills so the number of fish can increase.

\section{RESEARCH METHOD}

The mix-method approach is used to acknowledge the objectives of this study. The mix-method approach is a combined method of quantitative and qualitative approaches. Quantitative analysis in the form of descriptive statistics and chisquare test to analyze the results of interviews with respondents. While the qualitative analysis is in the form of an indepth interview with key informants. The first objective is the fishermen's perception of the benefits of information and communication technology explained by the chi-square test using software SPSS 23. While the second objective is the strategy for the role of stakeholders in the use of information and communication technology explained by using stakeholder analysis with the help of software Atlas. Ti 8 is described descriptively and confirmed by theory or previous research and phenomena or responses from respondents. 
This study uses primary data obtained directly in the field through interviews with the help of questionnaires to respondents and in-depth interviews with key informants. Respondents in this study are fishermen in Kedung Pancing Village, Bajomulyo Village, Alasdowo Village, and Dukuhseti Village in Pati Regency, Central Java. Meanwhile, the key informants in this study are stakeholders from the Academic, Business, Government, and Community (ABGD). The sample in this study is using the snowballing technique so that the number of samples used in this study is 89 respondents, this refers to Nurdiani, (2014) who suggested using sample $>30$ respondents for snowballing technique. Meanwhile, to determine the key informant using purposive sampling technique that is the determination of the sample is taken based on the parties who have a direct interest in the use of information and communication technology in the fishing community, so that the key informants in this study are the Undip Oceanography lecturer from the academic, the Department of Marine Affairs and Fisheries of Pati Regency and Central Java Province, and the Bajomulyo Coast Fisheries Port Staff from the government, vessel owner from the business element, and the head of the fishing group from the community.

\section{RESULT AND DISCUSSION \\ Result \\ Characteristics of Respondents}

Table 1 show the respondents in this study have the youngest age of 23 years old and the oldest 61 years old. The majority of respondents are in the age range of 41-50 years, which is classified as a productive age. The education level of the respondents consisted of various levels, there are 9 respondents not school, 36 respondents who graduated from elementary school, and graduated from junior high school and senior high school 22 respondents for each level. The majority of respondents have a low level of education because more than half of the respondents did not take formal education and only graduated from elementary school.

A total of 47 respondents or $52.81 \%$ of the total respondents are vessel owners, although the respondents have the status of vessel owners, most of them also go fishing with the crew or the captain. A total of 31 respondents or 34.83 are crew members $(A B K)$ and 22 respondents or $24.72 \%$ are the captains. Respondents go fishing with different periods, some from a day to a week, some even up to 30 days. From each trip, the income obtained by respondents is also different, most of the 38 respondents, or $42.67 \%$, have income below one million rupiahs. Which the income of respondents is determined by the number of fish, types of fish, and also the price of fish. The longer time for fishing, the more fish will respondents get, so the income will also increase.

\section{Fishermen's Perception of the Benefits of Using Information and Communi- cation Technology}

The information and communication technology used by respondents in this study is a global positioning system (GPS) used to locate the vessel's position, landing center, and locations where many fish are caught during the last trip. The echosounder is used to find groups of fish and corals. The mobile phone is used to communicate with agents to find out market prices and to contact their relatives (Sabu, et al 2017). In addition, internet access is also used by fishermen to find information about the weather in the sea such as wind direction, wave height, and wave currents. Based on the interviews conducted, there are $58.65 \%$ of respondents use information and communication technology (ICT) in fishing activities in the sea, and $31.35 \%$ of respondents do not use information and communication technology tools for fishing activities. Thus, it can be seen that 
the majority of respondents have used and utilized information and communication technology to assist them in fishing activities in the sea.

Information and communication technology is very useful in assisting fishermen to conduct fishing activities. Based on the results of interviews conducted with respondents can be show in the Table 2.

The above perception is obtained from the many emphases on sentences that state the benefits of the use of information and communication technology expressed by respondents during interviews that are then processed using an atlas. ti tools. Susilowati et al., (2020) also found about the perception of benefits to fishermen by using information and communication technology for fishing activities.

The use of information and communication technology can make it easier for fishermen to communicate, this is indicated by as much as 32 times the emphasis.

The benefits of using information and communication technology, which can reduce production costs, were emphasized 67 times by respondents when interviewed. This is in line with Osman, et al, (2014) and Omar, et al (2011) which explain that fishermen can shorten their fishing time, so this can save their operational costs. For example, the use of GPS can shorten the duration of fishermen in fishing, so they can use less fuel.

The use of technology and information can increase the safety of fishermen, this is emphasized 98 times.

Information technology can provide early warning about potential threats and can help fishermen to navigate safely to ports in case of bad weather (Fadzil et al., 2019). Fishermen will also feel safer when using technology when fishing in the sea to reduce mortality and other risks. ((Mazuki \& Man, 2014); (Torner \& Nordling, 2000)).

Information and communication technology can increase fishermen's knowledge, this benefit is felt by fishermen as evidenced by the emphasis on 24 times. As in the study conducted by Asirin \& Argo, (2017) which found that by using ICT fishermen can identify information and knowledge, the ability to recognize challenges and knowledge, and the ability to transfer and share knowledge. The last, information and communication technology can increase income, which is emphasized 56 times. This benefit is still related to the previous benefit, namely reducing production costs and more efficient fishing time, leading to an increase in fishermen's income.

\section{The Relationship between the Use of Information and Communication Tech- nology and Fishermen's Income}

As described above, the respondents have experienced many benefits by using information and communication technology. One of the benefits felt by respondents by using information and communication technology, which can make it easier and faster to determine potential fish areas so that can save fishing costs and increase the number of fish obtained which also increases fishermen's income. This is also expressed by (Bolong et al, 2013) stated that the use of fishing technology can increase the productivity and income of fishermen. According to (Fadzil et al., 2019), fishing technologies such as sonar and echo-sounder facilitate the fishing process to get more fish and increase the fishermen's income. This is considered more accurate than using the traditional method which relies heavily on weather stability and luck.

Based on the results of interviews conducted with respondents, which then tested a chi-square of the use of information and communication technology with fishermen's income to determine the relationship, it can be described in Table 3.

Based on the results of software SPSS 23 in the Table 3, the value of asymp 
is obtained. Sig (2-sided) or p-value of chisquare calculated $0.044<0.05$ level, which means that there is a relationship between the use of information and communication technology and income per fishing trip.

Sinrang, et al (2018) also explained that technology has a positive influence on the productivity and income of fishermen. Fishermen have used technology both in the form of using engine boats and operating equipment. The more sophisticated the technology used, the higher the productivity of fishermen, and the results obtained also increase. By increasing the fish the income obtained is also higher.

\section{Stakeholder Role Strategy in Utilizing the Use of Information and Communi- cation Technology}

The use of information and communication technology can not be separated from the role of the relevant stakeholders. (Susilowati et al., 2020) explained the role of stakeholders in increasing the use of information technology and information technology. (Nugroho et al., 2021) also explained how the role of stakeholders in overcoming the obstacles faced by fishermen in the use of information and communication technology. Based on in-depth interviews with key informants then processed using the software Atlas.Ti, the results are shown in Figure 2.

Table 1. Characteristics of Respondents

\begin{tabular}{|c|c|c|c|}
\hline Characteristic & Total & Percentage $(\%)$ & Description \\
\hline \multicolumn{4}{|l|}{ Age (years old) } \\
\hline $20-30$ & 12 & 13,48 & \\
\hline $312-40$ & 25 & 28,09 & $\operatorname{Min}=23$ \\
\hline $41-50$ & 30 & 33,71 & $\operatorname{Max}=61$ \\
\hline $51-60$ & 16 & 17,98 & Mean $=55,5$ \\
\hline$>60$ & 6 & 6,74 & \\
\hline \multicolumn{4}{|l|}{ Education Level } \\
\hline Not school & 9 & 10,11 & \\
\hline $\begin{array}{l}\text { Elementary } \\
\text { School }\end{array}$ & 36 & 40,45 & \\
\hline $\begin{array}{l}\text { Junior High } \\
\text { School }\end{array}$ & 22 & 24,72 & \\
\hline $\begin{array}{l}\text { Senior High } \\
\text { School }\end{array}$ & 22 & 24,72 & \\
\hline \multicolumn{4}{|l|}{ Status on vessel } \\
\hline Vessel Owner & 47 & 52,81 & \\
\hline Vessel Crew & 31 & 34,83 & \\
\hline Vessel Captain & 22 & 24,72 & \\
\hline \multicolumn{4}{|c|}{ The income per Trip (Rp) } \\
\hline$<1$ million & 38 & 42,67 & Min= 186.000 \\
\hline$>1-2$ Juta & 10 & 11,24 & $\mathrm{Max}=3.670 .000$ \\
\hline$>2-3$ Juta & 26 & 29,22 & Mean $=3.300 .000$ \\
\hline$>3-4$ Juta & 8 & 9 & \\
\hline$>4-5$ Juta & 5 & 5,62 & \\
\hline$>5$ Juta & 2 & 2,25 & \\
\hline
\end{tabular}




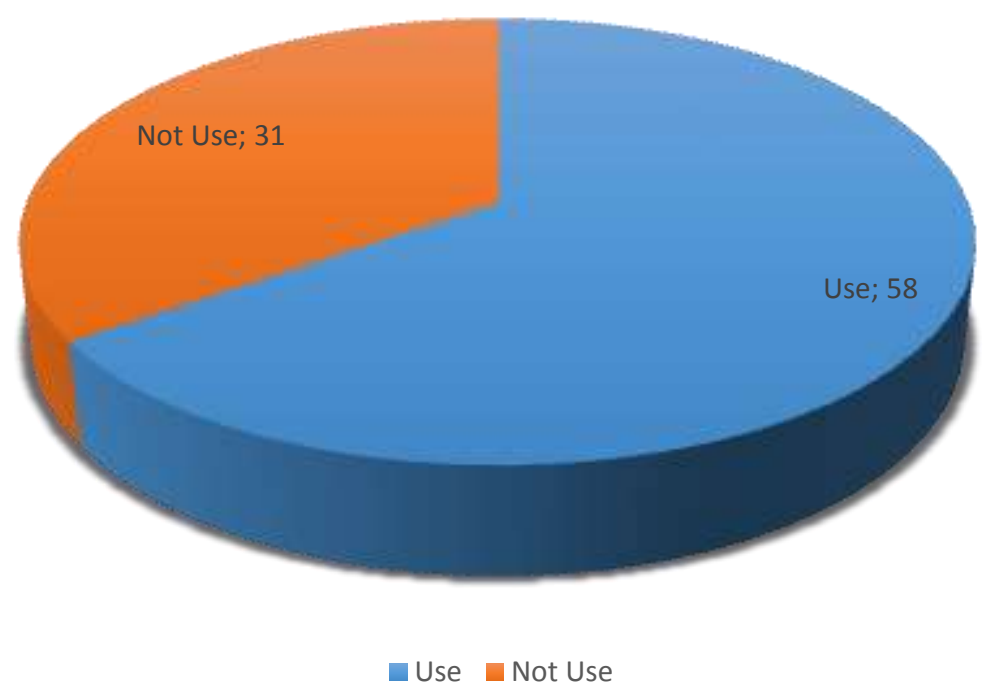

Figure 1. Respondents' Use of Information and Communication Technology Source: Processed data, 2021

Table 2. Fishermen's Perception of the Benefits of Using Information and Communication Technology

\begin{tabular}{clc}
\hline No & \multicolumn{1}{c}{ Benefits Perception } & Frequency \\
\hline 1. & Easily communicating & 32 \\
\hline 2. & Reduce production costs & 67 \\
\hline 3. & Increase safety & 98 \\
\hline 4. & Increase fishermen's knowledge & 24 \\
\hline 5. & Increase income & 56 \\
\hline
\end{tabular}

Source: processed data, 2021

Table 3. The Relationship between the Use of Information and Communication Technology (ICT) with Income per Fisherman Trip

\begin{tabular}{|c|c|c|c|c|c|c|c|c|}
\hline \multirow{2}{*}{\multicolumn{2}{|c|}{ use of ICT }} & \multicolumn{7}{|c|}{ The income per Trip (IDR) } \\
\hline & & $\begin{array}{l}<1 \\
\text { million }\end{array}$ & $\begin{array}{l}>1-2 \\
\text { million }\end{array}$ & $\begin{array}{l}>2-3 \\
\text { million }\end{array}$ & $\begin{array}{l}>3-4 \\
\text { million }\end{array}$ & $\begin{array}{l}>4-5 \\
\text { million }\end{array}$ & $\begin{array}{l}>5 \\
\text { million }\end{array}$ & Sig. \\
\hline \multirow{3}{*}{ ICT } & Use & 8 & 10 & 26 & 7 & 5 & 2 & \multirow{3}{*}{0.044} \\
\hline & Not use & 30 & 0 & 0 & 1 & 0 & 0 & \\
\hline & Total & 38 & 10 & 26 & 8 & 5 & 2 & \\
\hline
\end{tabular}

Source: processed data, 2021 


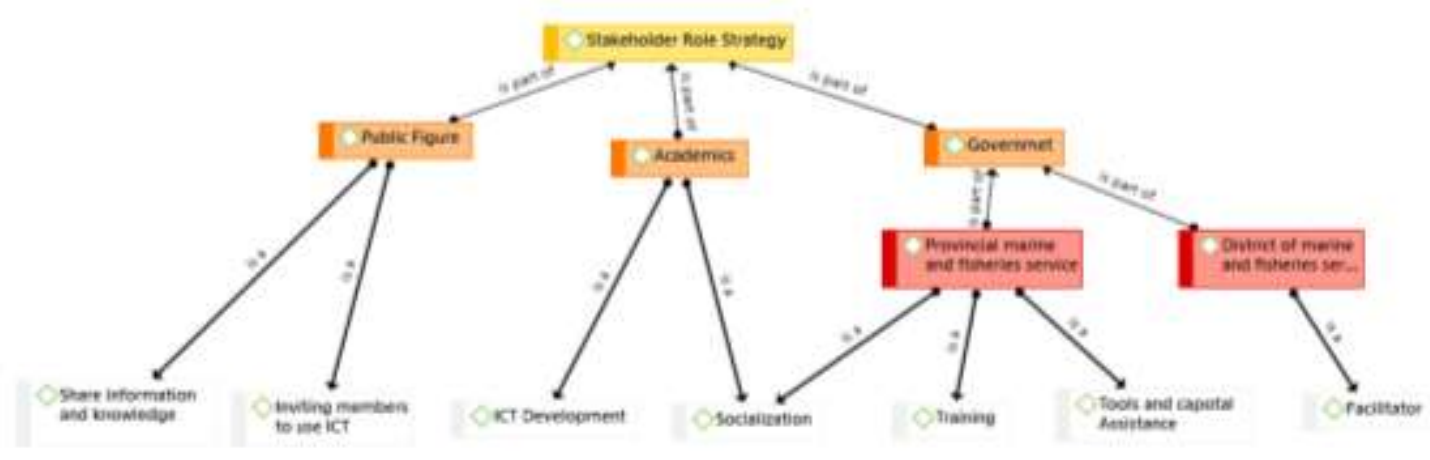

Figure 2. Stakeholder Role Strategy in Utilizing the Use of Information and Communication Technology in the fishing community

The government, in this case, the Provincial Marine and Fisheries Service and the Regency Fisheries and Marine Service have different roles because their duties, functions, and authorities are also different. The District Marine and Fisheries Service just as a facilitator from fishermen to higher government and vice versa. In addition, the Provincial Marine and Fisheries Service assists fishermen in resolving conflicts between fishermen, who go fishing in zone 1. Meanwhile, the Provincial Marine and Fisheries Service has a bigger role than the district service, such as providing socialization, training, and assistance in the form of tools and capital. This is as conveyed by the Department of Maritime Affairs and Fisheries of Pati Regency during an interview as follows:

"...hhhmm All is from the province, we are only facilitators. The most important is related to the safety of fishermen, the training is related to the safety of fishermen. The convey is related to regulations, laws, and training, that's all. Training, training as a facilitator, for example, training for nelayan pintar, just facilitator, like that. It is related to the safety of fishermen, the protection of fishermen, that is our authority. For example, the protection of fishermen is fisherman insurance. Even though since 2016 it was related to Law
No. 72016 it is related to fishery protection, it has also been fisherman insurance programmed by the Ministry of Maritime Affairs and Fisheries, which is existing, but related to fishermen's insurance...... Socialization can be Regency/City can be Province, training can be Regency/City can be Province, coaching can be Regency/City can be Province, If the province is wide, it covers everything. But in the district is only for service, it is only to serve. just the person, the tools are only for safety protection like that. If the convey related to the nelayan pintar application remains the authority of the Province. It is not solely the authority of the Province..."

From the academic, it has a role to educate as well as study and development on fisheries information and communication technology that is easier to use by fishermen. This is as stated by the Oceanography Lecturer when interviewed as a key person as follows:

"...the first is community involvement in the development of the system. The second is the education that is conducted continuously and the third is that fishermen require assistance"

The role of community leaders, in this case, is the head of the fishing group to share knowledge and information and 
invites members of the fishing group to use information and communication technology. Due to the large influence of fishermen's groups in fishermen's lives, fishing groups play a very important role in the use of information and communication technology. As stated by one of the fishermen group leaders who was interviewed as a key informant as follows:

"...Here if a member who uses something like that, it will be taught to others how to operate well, Ms. For example, A uses this tool and the results are more, surely later others will also want to, Ms."

So that the role of all stakeholders is very important in the use of information and communication technology in fishing communities in Pati Regency, Central Java

\section{Discussion}

The use of information and communication technology has a positive impact in the field of fisheries, especially for fishing communities. Information and communication technology is very helpful for the community, especially when carrying out fishing activities. As explained by Omar et al., (2011) regarding the benefits of information and communication technology such as GPS which helps fishermen mark the location of fish spots, return to potential fish areas and return to land. Sonar can help fishermen find movement, type and size of sonar shoals as well as information about the seabed. Fishermen use the internet to find out information about fisheries, such as weather conditions, market prices and so on. While cellphones are used by fishermen to disseminate and share information with fellow fishermen and their families. Meanwhile, Fadzil et al., (2019) explain the benefits of using technology and information in fishing communities, namely strengthening and facilitating social relations between fishermen, reducing production costs in the fishing process, increasing the safety of fishermen when carrying out fishing activities, increasing fishermen's knowledge and increasing fishermen's income. Based on these benefits, this study finds the benefits felt by fishermen when using information and communication technology which are explained by their perceptions. The results state that the benefits of information and communication technology are easily communicating, reduce production costs, increase safety, increase fishermen's knowledge and increase income.

Joshi \& Ayyangar, (2010) stated that the use of ICT such as mobile phones makes long-distance connectivity of fishermen to their families and fellow fishermen. As one of the respondents said when interviewed as follows:

"...yeah, if I usually use this mobile phone when I go fishing. The sea water can damage the device, so it's safe to take the good ones to the sea, so just take this one. Simply it can only make calls and SMS because difficult to access the signal. I usually use a mobile phone to notify family at home and ask friends, how much is the price there, Ms."

Information and communication technology is useful for improving the safety of fishermen, as stated by one of the respondents during the interview as follows:

"....we observe before fishing how the weather is. It is on the forecast in windy application to know how the weather is. For example, when the windy is strong we do not go fishing. It is dangerous."

One of the benefits obtained from the use of information and communication technology by the community is that it can reduce costs in fishing. Bolong et al., (2013) found that ICTs such as GPS can increase the productivity of fishermen by looking at the significant positive correlation between the use of ICT in the form of GPS and echo sounders with the income of fishermen in Malaysia. The 
increase in fishermen's income is also due to using ICT such as GPS, sonar, echo sounder, cellphone and other devices, which can save fishermen's time, money and energy in fishing (Shaffril, et al, 2012). Sabu \& Shaijumon, (2016) also found that the use of ICT was very helpful for fishermen in their fishing activities. The use of ICT such as GPS and mobile phones can help fishermen increase their income, which is indicated by the increased income of fishermen when using GPS and cellphones. This is also similar to what was found in this study, that there is a relationship between the use of ICT such as GPS, sounder, cellphone, and internet with fishermen's income. These results are supported by the statements of respondents who were interviewed as follows:

"...It does not save the fuel I think because we have allocated for a day. We adjust the cost. Just there we go fishing. It becomes faster to get the point, fish, and more fish. That is the benefit Ms."

The use of information and communication technology in fishing communities cannot be separated from the role of relevant stakeholders such as the marine and fisheries service, fishing groups, and academics. As stated by Nugroho et al., (2021) that in increasing fisheries development in this case through the use of information and communication technology requires intervention from the government and also institutions other than government such as fishing groups. Muliawan et al, (2014) also found that the role and involvement of stakeholders in fisheries resource management greatly influences its success. The same thing was also found in this study that the use of information and communication technology carried out by the fishing community cannot be separated from the role of stakeholders, namely the marine and fisheries service in Pati district and Central Java province, the head of fishing groups and academics. Although the role of each stakeholder is different, it is very important for the fishing community so that coordination between stakeholders is also needed for the improvement and continuation of fisheries development.

\section{CONCLUSION AND RECOMMEN- DATION}

Information and communication technology are very beneficial for fishing communities. Fishermen's perceptions of the benefits of information and communication technology used are facilitating communication, reducing production costs, increasing safety, increasing fishermen's knowledge, and increasing income. There is a relationship between the use of technology and information with fishermen's income, for example, if fishermen use GPS it will shorten the time to find potential fish areas so that the fishing activity takes longer and increases the amount of fish and the income will also increase. The use of information and communication technology by fishing communities is inseparable from the role of relevant stakeholders such as government, academics, and also community leaders who continue to encourage its use among fishing communities.

This study still has limitations, namely, it does not explain how much influence the use of information and communication technology has on fishermen's income per trip. This is required to find out how much influence the use of ICT by fishing communities has on income so that it can be seen whether the use of ICT affects the welfare of fishermen. Further study is expected to add to the magnitude of the influence. Is there a role between intersecting stakeholders? It can be known for further study.

\section{REFERENCES}

Akbar, T., \& Huda, M. (2017). Nelayan, lingkungan, dan peribahan iklim (Studi terhadap kondisi sosial ekonomi pesisir di Kabupaten Malang). Wahana, 68(1). 
Asirin, A., \& Argo, T. A. (2017). Penggunaan Teknologi Informasi dan Komunikasi dan Implikasinya terhadap Ketangguhan Mata Pencaharian Nelayan. Journal of Regional and Rural Development Planning, $\quad 1(1), \quad 1$. https://doi.org/10.29244/jp2wd.2017. 1.1.1-15

Bolong, J., Omar, S. Z., D'Silva, J. ., Shaffril, H. A. ., \& Hassan, A. . (2013). ICT utilization and its impacts on the income of young fishermen in Malaysia. Pertanika Journal of Social Sciences and Humanities, 21, 49-58.

Fadzil, M. F. B., Khairuddin, I., Bolong, J., \& Farid, S. (2019). Fishing Technology and Fisherman Community: A Narrative Review. International Journal of Academic Research in Business and Social Sciences, 9(12), 668-675. https://doi.org/10.6007/IJARBSS/v9i12/6760

Fargomeli, F. (2014). Interaksi Kelompok Nelayan Dalam Meningkatkan Taraf Hidup di Desa Tewil Kecamatan Sangaji Kabupaten Maba Halmahera Timur. Jurnal "Acta Diurna."

Fatmawati, E. (2015). Technology acceptande model (TAM) untuk menganalisis penerimaan terhadap sistem informasi perpustakaan. Jurnal Iqra', 9(1), 1-13.

Hassan, M. A., Shaffril, H. A. M., D'Silva, J. L., Omar, Z., \& Bolong, J. (2011). Fishermen and ICT: Towards creating knowledgeable fishermen in Malaysia. Australian Journal of Basic and Applied Sciences, 5(9), 457-469.

Jehan, N., Khalid, M., Aujla, K. M., \& Shahzad, M. (2014). Use of mobile phones by farming community and its impact on vegetable productivity. Pakistan Journal of Agricultural Research, 27(1), 58-63.

Joshi, H., \& Ayyangar, G. (2010). ICT: A Boon for Fishermen Community. Journal of Global Communication, $3(1), 8-13$.
Lamtane, H., Dulle, F. ., \& Bernard, R. (2018). The Influence of ICT Usage in Sharing Information on Fish Farming Productivityin the Southern Highlands of Tanzania. The International Journal of Science and Technoledge, 6(2), 56-67.

Mazuki, R., \& Man, N. (2014). Acceptance of technology among Malaysian fishermen. Asian Social Science, 10(16), 1-5. https://doi.org/10.5539/ass.v10n16p1

Muliawan, I., Fahrudin, A., Fauzi, A., \& Boer, M. (2014). Analisis Stakeholders pada Perikanan Tangkap Kerapu Preliminary Study Menuju Implementas Ecosystem Approach for Fisheries Management di Kepulauan Spermonde Kota Makassar. Jurnal Sosial Ekonomi Kelautan Dan Perikanan, 9(2), 233-246.

Nugroho, B. M., Susilowati, I., Thohir, M., Prastyadewi, I., \& Suciati, I. (2021). Fishermen behavior in the use of information and communication technologies ( ICTs ) in Central Java Province, Indonesia: Comparative study in Pati and Pemalang regencies. 14(5), 2698-2707.

Nurdiani, N. (2014). Teknik Sampling Snowball dalam Penelitian Lapangan. ComTech: Computer, Mathematics and Engineering Applications, 5(2), 1110.

https://doi.org/10.21512/comtech.v5i2 .2427

Omar, S. Z., Hassan, M. A., Shaffril, H. A. M., Bolong, J., \& D 'silva, J. L. (2011). Information and communication technology for fisheries industry development in Malaysia. African Journal of Agricultural Research, 6(17), 41664176.

Osman, M. ., Omar, S. Z., Bolong, J., D'silva, J. ., \& Shaffril, H. A. . (2014). Raidiness of young Malaysian fishermen to use global positioning system within the fishing operation. Asian Social Science, 10(14), 1-7. 
Otter, V., \& Theuvsen, L. (2014). ICT and farm productivity: Evidence from the chilean agricultural export sector. Lecture Notes in Informatics (LNI), Proceedings - Series of the Gesellschaft Fur Informatik (GI), P226, 113-116.

Perdana, T. A. (2015). Dampak Pemanasan Global Terhadap Nelayan Tangkap ( Studi Empiris di Pesisir Utara Kota Semarang ).

Retnowati, E. (2011). Nelayan Indonesia dalam Pusaran Kemiskinan Struktural (Perspektif Sosial, Ekonomi dan Hukum). Perspektif, 16(3), 149-159.

Sabu, M., \& Shaijumon, C. S. (2016). Usage level of ICT and its impact on income among mechanised and motorised marine fishermen in Kerala, India. Pertanika Journal of Social Sciences and Humanities, 24(2), 605-618.

Sabu, M., Shaijumon, C. S., \& Rajesh, R. (2017). Factors influencing the adoption of ICT tools in Kerala marine fisheries sector: an analytic hierarchy process approach. Technology Analysis and Strategic Management, 30(7), 866-880. https://doi.org/10.1080/09537325.201 7.1388363

Salam, A., Fachrussyah, \& Chairil, Z. (2021). Adaptasi Dan Inovasi Teknologi Perahu Nelayan Dan Alat Tangkap Tradisional Di Teluk Tomini. Journal of Marine Fisheries Technology and Management, 12(1), 101-111.

Shaffril, H. A. M., Omar, S. ., Hassan, A. M., Bolong, J., \& D'Silva, J. L. (2012). Measuring ICT usage among west coast fishermen: Pre-test results from Port Dickson, Negeri Sembilan. American Journal of Agricultural and Biological Sciences, 7(1), 21-27.

Sinrang, A. D. B., Mus, A. R., Hamzah, M. N., \& Gani, A. (2018). Influence of competence, and technology on productivity and fishermen fisheries income in south Sulawesi province. International Journal of Scientific and Technology Research, 7(9), 110-116.

Susilowati, I., Thohir, M., Sbm, N., \& Suciati, I. (2020). Pemanfaatan aplikasi nelayan pintar di Kabupaten Pati - Jawa Tengah. Jurnal Ekonomi Dan Bisnis, 23(2), 243-262.

Tasmil, \& Herman. (2015). Penerapan model TAM untuk menilai tingkat penerimaan nelayan terhadap penggunaan GPS. Jurnal Pekommas, 18(3), 161-170.

Torner, M., \& Nordling, P. . (2000). Occupational injury in Swedish fishery: Analysis of injury statistics. Occupational Ergonomics, 2(2), 8189.

Tyas, D. P. (2016). Analisis Persepsi Masyarakat Nelayan Tradisional terhadap Daerah Penangkapan Ikan di Teluk Banten. Universitas Indonesia.

Wijaya, A., Rochmah, S., \& Ismani. (2009). Manajemen Konflik Sosial dalam Masyarakat Nelayan. Jurnal Malang.

Wiryadi. (2015). Manfaat Satelit Bagi Masyarakat Nelayan. Retrieved, 11(3). 